\title{
Evaluation of soil changes resulting from application of vetiver (Vetiveria Nigritana) grass technology on sloppy urban farm in Uyo,Akwa lbom state
}

\begin{abstract}
In order to meet the long-term objective of agricultural development at the instant of high demand for land in urban centre, the importance of erosion control in relation to vetiver grass technology on acid sand soils of Uyo was adopted. The potentials of vetiver grass strips technology in improving the fertility status of eroded land after four years were classified into three suitability classes viz: Highly suitable, suitable and moderately suitable. The soils are suitable for arable crops but with varying degree of suitability that requires management practices. The soils of mapping unit-A (suitable) are highly acidic with low available water content and relatively low fertile. Their major fertility constraints include high bulk density, the sandy nature and low potassium reserve. Mapping unit-B (highly suitable) are the main agricultural soils of the land area with sandy surface layer with high exchangeable bases, while soil of Mapping unit-C (moderately or conditionally suitable) are poorly drained and are good for short-season crops like vegetables during the short dry period of the year. From the study, the soils is fragile and sloppy, therefore, easily eroded (mapping unit-A) especially as the zone is in the high rainfall region. For the soils to be made fertile and productive, grass strip of $10 \mathrm{~m}$ interval is recommended with fertilizer, unavoidable if optimum yields of crops are to be obtained
\end{abstract}

Keywords: vetiver, infiltration capacity, kaolinit, erosion mapping unit, suitability
Volume 2 Issue 2 - 2017

\author{
Edem ID,' IK Gideon ${ }^{2}$ \\ 'Department of Soil Science and Land Resources Management, \\ University of Uyo, Nigeria \\ ${ }^{2}$ Department of Forestry \& Natural Environmental Management, \\ University of Uyo, Nigeria
}

Correspondence: Eeam ID, Department of Soil Science and Land Resources Management, University of Uyo, Nigeria, Email dennis.edem@gmail.com

Received: February 03, 2017| Published: APRIL 10, 2017

\section{Introduction}

Land evaluation is only a part of the process of land use planning. It is concerned with the assessment of land performance when used for specific purpose. It involves the execution and interpretation of basic surveys of climate, soils, vegetation and other aspect of land in terms of the requirements of alternative forms of land use. ${ }^{1}$ It precise role varies in different circumstances. In this present context, the land use planning is sufficiently presented by the generalized sequence of crop activities decisions are based. Among the different land degradation processes, water that is often the main limiting factor of crop production is also the main factor directly or indirectly responsible for soil and land degradation processes (Pla, 1997). Accelerated erosion is often a major concern globally today not only because it is widespread but because its consequences on the environment (land, water and air), which constitute a serious threat to human existence (Brown and Wolf, 1984). The average farmer today is perhaps not convince that soil conservation brings about an improvement in soil quality and increase in crop productivity even in short term. This of why these farmers engage in indiscriminate bush burning and mechanical bush clearing leaving the fragile topsoil expose to the dreadful surface water erosion. Probably because many of these measures are expensive in terms of cost of establishment and material required. In deciding what conservation measures to employ, preference should be given to agronomic treatments that are less expensive towards a sustainable agriculture. Hence Vetiver grass technology becomes handy.

Vetiver grass grows in Nigeria but its potential for soil and water conservation has not been realized. However, Babalola et al. ${ }^{9}$ have demonstrated the usefulness and efficacy of vetiver grass strips as a soil and water conservation measure. Since it appears that erosion by water is more widespread and more serious relative to wind erosion, in Southern Nigeria, in order to explore the use of Vetiver grass technology for effective soil and water conservation, the study aimed at assessing the adaptability and effect of vetiver grass strips on soil physico-chemical properties and its fertility status. This report is an evaluation of changes in soil properties from soil data generated through field and laboratory testing. Note, soils comprised of solid, liquid and gas. In general, soil consists of approximately $45 \%$ mineral material, $5 \%$ organic and $50 \%$ pore space through which liquid and gases move. Based on the relationship of these components, careful management of land is required to create an ideal condition for optimum plant growth and healthy soil. The results of the marching process were combined with those of assessment of input and benefits, environmental impact, and economic analysis to produce a classification, showing the suitability of each land mapping unit for each relevant kind of land use. A field check is essential in order to ensure that the suitability classes arrived at are in accord with tests and experience judgment. ${ }^{2-5}$

\section{Materials and methods}

\section{Experimental sites}

The study was conducted at Uyo, and this area lies between latitude $4^{0} 30^{1}$ and $5^{0} 31^{1} \mathrm{~N}$ and longitude $7^{0} 31^{1}$ and $8^{0} 20 \mathrm{E}$ and altitude $65 \mathrm{~m}$ from the sea level. With two distinct seasons; the wet or rainy and dry seasons. The wet or rainy season begins from April and lasts till October. It is characterized by heavy rainfall of about $2500-4000 \mathrm{~mm}$ per annum. The rainfall intensity is very high and there is evidence of 
high leaching and erosion menace associated with slope and rainfall factors in the area. The rainfall is bimodal with peaks in July and September and a relative moisture stressed period in August known as "August break" (Edem, 2005).

The dry season starts from November and last still March. It is characterized by high temperature with a mean annual temperature of $28^{\circ} \mathrm{C}$. The highest temperature is experienced between January through March, the period described by Enwezor et al. as overhead passage of the sun. Relative humidity is between $75 \%$ and $95 \%$. The landscape is generally undulating to steep hills, while the vegetation is mainly; the tropical rainforest. The soils are derived from sandy parent materials which are weathered with low activity of clay (Udo and Sobulo, 1981). The soils have low content of organic matter, cation exchange capacity, base saturation and low $\mathrm{pH}$. The soil in the area is formed on costal plain sands parent materials and has been described as typic paleudult (Loganathan and Sutton, 1986)

Administration of questionnaire: Prior to the extension of vetiver grass technology to the farmers, there was a structured questionnaire to interview farmers within the farming communities of Uyo urban. This aimed at obtaining background information on the awareness of the farmers on soil conservation measures, their farming and cropping systems, and their willingness to adopt vetiver grass technology. ${ }^{6,7}$

On-farm demonstration: The on-farm demonstration was similar to small plot adoption technique (SPAT). Four farmers from different farming locations within area where the research was sited were chosen to participate in the demonstration. Each farmer had his own plots with the application of Vetiver grass technology as mulch and strips. ${ }^{8}$

Measurement of soil loss by erosion pin: Erosion pins (calibrated rods) of $30 \mathrm{~cm}$ length were installed $30 \mathrm{~cm}$ away from Vetiver grass strips (VGS) and $15 \mathrm{~cm}$ buried in the soil to ensure firmness on the upslope side of the strips to measure soil accumulation within the immediate upslope environs of the Vetiver strips. Two pins were installed per VGS in all the experimental plots at the beginning of the cropping season. Also, erosion pins were installed at the same interval of VGS for vetiver grass mulching and no Vetiver (control) plots. The length of rods (erosion pins) above the soil surface at the time of measurement was used to calculate the height of soil accumulation in VGS plot and removal of surface soil relative to the original level as at the time of installation. On the control plot, there was removal of soil instead of accumulation. The height of accumulated had a positive value while that of the exposed soil had negative value. The summation of both the positive and the negative values determined the actual height of soil exposed after rainfall. ${ }^{9}$

\section{Computation of erosion parameter}

Soil-erodibility factor (K):Due to time constraint, and cost of installations, the erodibility of these study sites were measured by the nomograph method in Renard et al. which is less expensive and time consuming. The method involves the determination of four different soil parameters namely, soil texture, soil structure, organic matter content and profile permeability (Edem et al.). The particle size analysis for the determination of soil texture is based on the USDA particle size limits while soil structure and profile permeability were coded according to Wischmeier and Smith and O'Neal respectively as reported by Edem and Inim. Values of these parameters were substituted into the erodibility equation which states that:

$$
100 k=2.1 m^{1.14}\left(10^{4}\right)(12-a)+3025(b-2)+2.5(C-3)
$$

Where; $\mathrm{K}$ = erodibility (t.ha.h.ha- $\mathrm{mm}^{-1}$ )

$\mathrm{M}=$ particle size parameter expressed as (\% silt $+\%$ very fine sand)(100-\%clay)

$$
\begin{aligned}
& a=\% \text { Organic matter } \\
& b=\text { structure code } \\
& c=\text { profile permeability code }
\end{aligned}
$$

Infiltration test: Field infiltration run on each experimental plot was conducted using double ring infiltrometer as described by Bouwer. The inner ring $(30 \mathrm{~cm}$ in diameter) was positioned at the center of the outer ring $(50 \mathrm{~cm}$ in diameter) (Plate 1$)$. The two rings were driven down uniformly with a hammer to a depth of $15 \mathrm{~cm}$, with a cross bar on top of the rings. In order to prevent the puddling of the soil surface when adding water into the infiltrometer, some pieces of dried grasses were laid within the rings. Water was added to the outer ring and the inner ring simultaneously. Water, however was maintained at the same level in both the inner and the outer rings. The outer ring acted as a buffer to prevent lateral flow of water from the inner ring, while vertical flow of water into the profile was achieved. Measurement of infiltrated water was taken at 1 minute interval, up to 30 minutes. Thereafter, the measurements were taken every 5 minutes until steady state at about 120 minutes. A ruler (float), graduated in centimeters was fixed vertically inside of the inner ring to record the falling in height of the water level at the successive times. The results of the infiltration obtained were fitted into Philip's and Kostiakov's models, and the infiltration characteristics were determined.

Fitting of the data into infiltration equations: Infiltration data were fitted into differential Phillip's vertical flow equation ${ }^{10}$ and Kostiakov's equation. ${ }^{9}$ From these equations, estimates of saturated hydraulic conductivity, sorptivity rates, and stability of aggregates, were possible.

\section{Differential phillip's equation:}

$$
d i / d t=i .=1 / 2 S t^{1 / 2}+A
$$

Where,

$$
\mathrm{i}=\text { instantaneous infiltration rate }
$$

A curve of di/dt against $t 1 / 2$ is a straight line with $\mathbf{A}$ as the intercept and $\mathbf{S}$, the slope of the curve.

\section{Kostiakov's equation}

$$
I=C t^{\alpha}
$$

Where, $\mathrm{I}=$ cumulative infiltration $(\mathrm{cm}), \mathrm{C}=$ index of the rate at which water enters the soil. The higher the value of $\mathrm{C}$, the larger the soil pores and vice versa

$\alpha=a$ measure of stability of the soil aggregates as water moves down the soil profile. The higher the value of $\alpha$, the more stable is the soil aggregates. 


$$
\text { t. = time interval (min.) }
$$

Soil sampling procedure: Prior to the cropping season, vetiver grass was planted in strips at designated plots provided by the farmers. Soil samples were collected with sampler between $0-15 \mathrm{~cm}$ depth at every $5 \mathrm{~m}$ interval within each demarcated farm plot $30 \mathrm{~m}$ by $4 \mathrm{~m}$ in all the experiments. Five sampling points were made within $5 \mathrm{~m}$ spacing in a diagonal form and the soil samples from the five points were bulk together. The pre-cropping season sampling was to ascertain the base line properties of the soil. Other samplings were carried out at the end of the season to find out whether the inherent fertility status of the soil is due to treatment imposed.

\section{Laboratory analyses}

Aggregate size distribution: Aggregate size distribution was determined by wet sieving method of Toddler as cited by Klute $100 \mathrm{~g}$ of soil sample was weighed into a moisture can $\left(\mathrm{W}_{1}\right)$ and was then transferred into a nest of sieve which were separated into various sizes by sieving the sample under a basin of water. These sieves were $4 \mathrm{~mm}, 2 \mathrm{~mm}, 1 \mathrm{~mm}, 0.5 \mathrm{~mm}$ and $0.25 \mathrm{~mm}$. The samples were placed in the upper sieve $(4 \mathrm{~mm})$. The nest of sieves containing the soil samples were then lowered into and out of water for 20 times. The sample in the sieve were then transferred to moisture can and oven dried at $105^{\circ} \mathrm{c}$ and the soil sample in the moisture can were all weighed and recorded as $\left(\mathrm{W}_{2}\right)$. Progressively, a dispersing agent sodium hexameter phosphate (calgon) $20 \mathrm{ml}$ was added and $30 \mathrm{ml}$ of water was also added in a Stirring cup containing the oven dried sample and was stirred for 5 minute each using a mechanical stirrer. The samples in the stirring cup were then transferred into a 210 micro meter sieve and were washed into the respective moisture cans by using wash bottle, and were finally oven dried to a constant weight at $105^{\circ} \mathrm{c}$; weight were accurately taken and recorded as $\left(\mathrm{W}_{3}\right)$ and then their percentages determined.

It was computed as follows

$$
\% W S A=\frac{W_{2}-W_{3}}{W_{1}-W_{3}} \times 100
$$

$$
W_{1}-W_{3}
$$

Where

$$
\begin{aligned}
& W S A=\text { Percent water stable aggregates } \\
& W_{1}=\text { mass of the initial soil }(\mathrm{g}) \\
& W_{2}=\text { mass of resistance aggregates plus sand fraction }(\mathrm{g}) \\
& W_{3}=\text { mass of sand fraction alone }(\mathrm{g})
\end{aligned}
$$

Particle size analysis: The aggregates of each soil sample were ground, passed through a $2 \mathrm{~mm}$ sieve and mixed. The individual samples were used for physical and chemical analyses. The particle size distribution was determined using the Day's hydrometer method as described by Klute. The soil particles after dispersing with sodium hexametaphosphate was stirred in a mechanical stirrer and were separated into coarse sand using $210 \mathrm{um}$ sieve, fine sand using 100um sieve and very fine sand using $50 \mathrm{um}$ sieve sizes. The textural classes of the various soil samples were determined using the textural triangle. The weight of silt was taken in the first hydrometer reading while that of clay was taken at the second hydrometer reading which was after 2 hours from the time the second hydrometer reading was taken.

The following physico-chemical properties of the soil were examined with soil samples collected from the field. The experiment consisted of two treatments; vetiver grass mulch (VGM) and nonvetiver plots replicated three times on a $6 \%$ slope. The treatments were arranged in a Randomized Complete Block Design (RCBD). Least significant difference (LSD) was used to compare the means. Coefficient of variation and Correlation analyses were carried out to measure degree of variation of infiltration characteristics among plots and the relationship of infiltration characteristics with soil properties. In order to establish a rational basis for selecting soil properties predictive of infiltration process, multiple regressions were performed according to the SPSS manual ${ }^{11}$ using stepwise selection and backward elimination techniques.

\section{Results and discussion}

\section{General soil patterns}

The colour of the soil is perhaps its most obvious characteristic. Along with texture and structure, it forms the basis for soil classification. ${ }^{12}$ As reported by, ${ }^{13}$ colours seen in the field results from the mixing of colours formed by mineral and organic matter. A redbrown colour may be formed from a mixture of red iron oxide and brown organic matter. Organic matter build up in sand can be seen by a greying in the top $20 \mathrm{~cm}$. In this study area, colour was objectively assessed by comparing the colour of a freshly broken surface of moist soil with the standard Munsell Soil Colour Charts. Routine soil analyses were done and the attributes grouped to form the soils' mapping units (Table 1).

Table I Soil Variables and their analytical methods.

\begin{tabular}{ll}
\hline Soil variables & Soil variables \\
\hline Particle size distribution & $\begin{array}{l}\text { Day's hydrometer method (day, } \\
1965)\end{array}$ \\
$\mathrm{pH}($ water-1:2.5) & $\begin{array}{l}\text { Standard glass electrode method } \\
\text { Walkley-Black method (Walkley } \\
\text { and Black, 1934) }\end{array}$ \\
Organic carbon $(\mathrm{g} / \mathrm{kg})$ & Keljdahl method (Bremner, 1965)
\end{tabular}

Available P (mg/kg) Bray1-P method (Bray and Kurtz,

Calcium $(\mathrm{cmol} / \mathrm{kg})$

Potassium $(\mathrm{cmol} / \mathrm{kg})$

Sodium $(\mathrm{cmol} / \mathrm{kg})$

Magnesium $(\mathrm{cmol} / \mathrm{kg})$

\section{Determination of Infiltration characteristics using Philips and Kostiakov's models}

Infiltration data generated were fitted into Philip's and Kostiakov's equations (Table 2) for determination of the sorptivity and transmisivity of the soil. The $\mathrm{R}^{2}$ Value for both infiltration models range between 0.63 and 0.99 implying that both models fit the data very well and can adequately predict infiltration rates into the soil under vetiver and non-vetiver hedge management. At a distance of 
$25 \mathrm{~cm}$ infiltration point away from the vetiver, absorptivity of the soil's upper layer (A) had a mean value of $3.9 \mathrm{cmmin}^{-1}$, while the infiltration points at $50 \mathrm{~cm}$ distance away from vetiver recorded a mean of $2.2 \mathrm{~cm} \mathrm{~min}^{-1}$. Relatively, infiltration rate at $25 \mathrm{~cm}$ distance away from the vetiver grasses transmit water more than the distance of $50 \mathrm{~cm}$ away from the vetiver hedges. The same trend was true for rate of water Sorptivity (S), Kostiakov's index of soil pore sizes(C), and index of soil stability $(\alpha)$. $\left(\mathrm{S}=242.22 \mathrm{cmmin}^{-1}>171.79 \mathrm{cmmin}^{-1)}\right.$ and $\left(\mathrm{C}=4.19 \mathrm{cmmin}^{-1}>3.59 \mathrm{cmmin}^{-1}, \alpha=2.88 \mathrm{cmmin}^{-1}>2.54 \mathrm{cmmin}^{-1}\right)$. Soils at the distance of $25 \mathrm{~cm}$ from the vetiver were relatively seen to be more structurally stable than those at $50 \mathrm{~cm}$ distance away from the vetiver hedges. The results in no-vetiver plots were similar to $50 \mathrm{~cm}$ distance in the vetiver plots (not significantly different).

Table 2 Infiltration characteristics of soils under Vetiver and No - Vetiver plots determined at $25 \mathrm{~cm}$ from the line of vetiver hedge

\begin{tabular}{|c|c|c|c|c|c|c|c|c|c|c|}
\hline \multirow{2}{*}{ Infil. test } & \multicolumn{5}{|c|}{ Philips' model } & \multicolumn{3}{|c|}{ Kostiakov's model } & \multirow[b]{2}{*}{ i. $(\mathrm{cm} / \mathrm{hr})$} & \multirow{2}{*}{$\begin{array}{l}\text { Cumulativeinfiltration } \\
(\mathrm{cm} / \mathbf{2 h r})\end{array}$} \\
\hline & $\mathbf{S}$ & Mean & $\mathbf{A}$ & Mean & $\mathbf{C}$ & Mean & $\mathbf{A}$ & Mean & & \\
\hline $1 \mathrm{~A}$ & 187.04 & \multirow{3}{*}{161.46} & 1.4 & \multirow{3}{*}{1.9} & 1.99 & \multirow{3}{*}{1.75} & 0.94 & \multirow{3}{*}{0.92} & 2.02 & 97.2 \\
\hline $1 \mathrm{~B}$ & 135.88 & & 1 & & 1.51 & & 0.9 & & 0.65 & 76.4 \\
\hline $2 \mathrm{~A}$ & 139.55 & & 1.2 & & 1.62 & & 0.98 & & 0.67 & 81.9 \\
\hline $2 B$ & 113.54 & \multirow{2}{*}{126.55} & 1 & \multirow{2}{*}{1.1} & & \multirow{2}{*}{1.51} & 0.95 & \multirow{2}{*}{0.97} & 0.41 & 56.2 \\
\hline $3 \mathrm{~A}$ & 188.71 & & 2 & & 2.29 & & 0.99 & & 1.87 & 102.1 \\
\hline 3B & 149.56 & \multirow{2}{*}{169.14} & 1 & \multirow{2}{*}{1.5} & 1.99 & \multirow{2}{*}{2.14} & 0.83 & \multirow{2}{*}{0.91} & 0.57 & 87.4 \\
\hline $4 \mathrm{~A}$ & 131.72 & & 3 & & 3.02 & & 0.91 & & 0.8 & 108.9 \\
\hline 4B & 83.29 & \multirow{2}{*}{107.17} & 0.5 & \multirow{2}{*}{2} & 1.5 & \multirow{2}{*}{2.26} & 0.83 & \multirow{2}{*}{0.87} & 0.84 & 80.9 \\
\hline $5 \mathrm{~A}$ & 109.47 & & 0.5 & & 0.2 & & 0.95 & & 1.44 & 60.8 \\
\hline $5 B$ & 67.35 & \multirow{2}{*}{88.41} & 0.2 & \multirow{2}{*}{0.35} & 0.5 & \multirow{2}{*}{0.35} & 0.84 & \multirow{2}{*}{0.9} & 0.29 & 31.6 \\
\hline $6 \mathrm{~A}$ & 97.24 & & 0.5 & & 0.5 & & 1.02 & & 0.46 & 58.8 \\
\hline $6 \mathrm{~B}$ & 56.71 & 76.97 & 0.5 & 0.5 & 0.5 & 0.5 & 0.93 & 0.97 & 0.21 & 30.5 \\
\hline
\end{tabular}

Where, I, equilibrium infiltration; S, sorptivity; A, absorptivity; C, rate of water entry (Kostiakov constant); $\square$, measure of soil stability; Infil. Test, Infiltration at different locations; (Odds numbers=Vetiver plots and Even numbers=control plots).

In Philips' model, the mean sorptivity (S) of water in the soil ranged from $28.36-94.36 \mathrm{~cm} / \mathrm{min}$. The mean values were $80.73 \mathrm{~cm} /$ $\min , 63.28 \mathrm{~cm} / \mathrm{min}, 84.57 \mathrm{~cm} / \mathrm{min}, 53.5 \mathrm{~cm} / \min 44.05 \mathrm{~cm} / \mathrm{min}$ and $38.45 \mathrm{~cm} / \mathrm{min}$ for plots $1,2.3,4,5$ and 6 respectively. The highest sorptivity was observed in plot 3 (Point $3 \mathrm{~A}=94.36 \mathrm{~cm} / \mathrm{min}$ ). Mean hydraulic conductivity (A) ranged from $0.35-2.0 \mathrm{~cm} / \mathrm{min}$ and the respective plot mean values were $1.9 \mathrm{~cm} / \mathrm{min}, 1.1 \mathrm{~cm} / \mathrm{min}, 1.5 \mathrm{~cm} /$ $\min , 0.35 \mathrm{~cm} / \mathrm{min}, 2.0 \mathrm{~cm} / \mathrm{min}$, and $0.5 \mathrm{~cm} / \mathrm{min}$. The highest hydraulic conductivity (A) was recorded in plot 4 (Point $4 \mathrm{~A}=3.0 \mathrm{~cm} / \mathrm{min}$ ). In Kostiakov's model, the index at which water enters the soil (C) recorded mean range of $0.35-2.26 \mathrm{~cm} / \mathrm{min}$. But the respective plot means value were $1.75 \mathrm{~cm} / \mathrm{min}, 1.51 \mathrm{~cm} / \mathrm{min}, 2.26 \mathrm{~cm} / \mathrm{min}, 2.14 \mathrm{~cm} /$ $\min , 0.35 \mathrm{~cm} / \mathrm{min}$, and $0.50 \mathrm{~cm} / \mathrm{min}$. Plot 4 recorded the highest intake of water ( Point $4 \mathrm{~A}=3.02 \mathrm{~cm} / \mathrm{min}$ ). The index that measured the stability of soil aggregate $(\alpha)$ had a mean range value from 0.87 0.97. The respective plot mean values were, $0.92,0.97,0.91,0.87$, 0.90 and 0.97 . Equilibrium infiltration was moderate at $25 \mathrm{~cm}$ distance near vetiver hedges and the highest was recorded in plot $1(2.02 \mathrm{~cm} /$ $\mathrm{hr}$ ), while the highest in the control was $0.84 \mathrm{~cm} / \mathrm{hr}$. Generally, it ranged from $0.4-2.02 \mathrm{~cm} / \mathrm{hr}$. with a mean value of $0.64 \mathrm{~cm} / \mathrm{hr}$. in vetiver plots and from $0.3-0.64 \mathrm{~cm} / \mathrm{hr}$ with a mean of $0.51 \mathrm{~cm} /$ hr. in non-vetiver plots. Cumulative infiltration under vetiver plots ranged from $86.8-94.72 \mathrm{~cm} / 120 \mathrm{~min}$ and $44.7-94.9 \mathrm{~cm} / 120 \mathrm{~min}$. in the control, while the respective plot means values were $86.8 \mathrm{~cm} / 120 \mathrm{~min}$, $69.1 \mathrm{~cm} / 120 \mathrm{~min}, 94.8 \mathrm{~cm} / 120 \mathrm{~min}, 94.9 \mathrm{~cm} / 120 \mathrm{~min}, 46.2 \mathrm{~cm} / 120 \mathrm{~min}$, and $44.7 \mathrm{~cm} / 120 \mathrm{~min}$., the seventh infiltration point also recorded the highest cumulative infiltration ( Point $7 \mathrm{~A}=108.9 \mathrm{~cm} / 120 \mathrm{~min}$.).

\section{Influence of infiltration and soil characteristics on runoff under vertiver grass strips}

As shown in Table 3, the relationship of selected soil properties and infiltration characteristics with runoff water revealed a positive correlation between find sand and runoff $(r=0.6450)$ and negative correlation with porosity and sorptivity $(\mathrm{r}=-0.7650$ and -0.895 respectively) (Figure 1)

Table 3 Relationship between selected soil properties and infiltration characteristics with runoff water

\begin{tabular}{llll}
\hline \multirow{3}{*}{ Runoff } & \multicolumn{3}{l}{ Regression model } \\
\cline { 2 - 4 } & $0.0404-19.416 \mathrm{CS}$ & $\mathbf{r}$ & $\mathbf{R}^{2}$ \\
\cline { 2 - 4 } & $0.1475+2.2301 \mathrm{FS}$ & 0.6450 & 0.3519 \\
& $0.1397-3.9607 \mathrm{SL}$ & -0.9971 & 0.9943 \\
\hline \multirow{3}{*}{ Soil properties } & $-0.039+11.95 \mathrm{CL}$ & 0.545 & 0.0416 \\
& $-27.881+46.647 \mathrm{BD}$ & 0.2502 & 0.0626 \\
& $1.6863-73.146 \mathrm{P}$ & -0.7650 & 0.5867 \\
& $-0.0078+7.6232 \mathrm{I}$ & 0.1435 & 0.0206 \\
Infiltration & $0.0821+1.379 \mathrm{CM}$ & 0.4188 & 0.1754 \\
characteristics & $0.055-0.0629 \mathrm{~S}$ & -0.8956 & 0.2298 \\
& $5.1643-1.6824 \mathrm{~A}$ & -0.2300 & 0.0716 \\
& $1.2935+5.8887 \mathrm{C}$ & 0.4793 & 0.0529 \\
& $457.5-408.71 \alpha$ & -0.2676 & 0.8022 \\
\hline
\end{tabular}



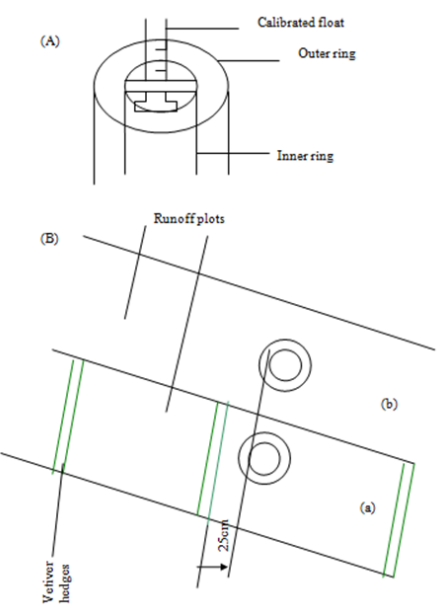

Figure I A diagram showing the double ring infiltrometer $(A)$ and $(B)$ the location of Double-Ring Infiltrometer on the (a) vetiver plot and (b) nonvetiver plot.

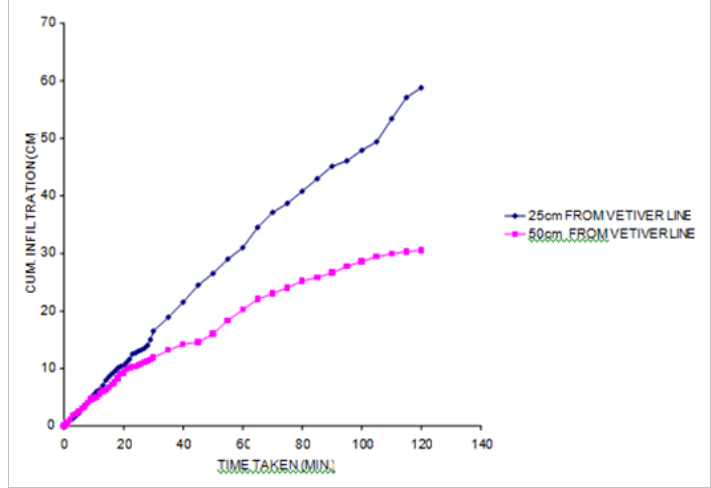

Figure 2 Cumulative infiltration against time elapsed for no-vetiver plot at 25 and $50 \mathrm{~cm}$ distances

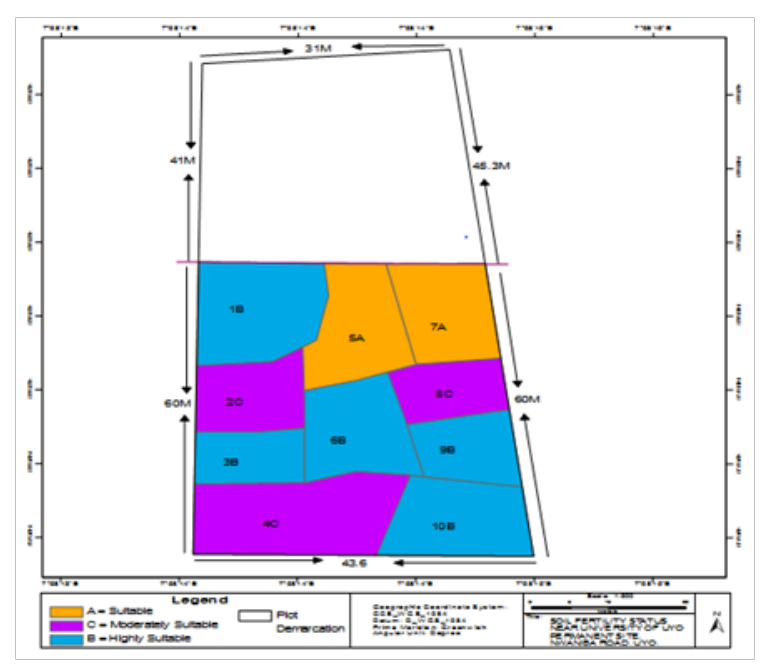

Figure 3 Soil fertility status near University of UYO permanent site.

\section{Infiltration characteristics under vetiver and non- vetiver plots}

Comparatively (Figures $2 \&$ Figure 3), infiltration characteristics under vetiver hedges were higher than those in the non- vetiver plots although the reverse was true for the index that measured soil stability $(\alpha)$. This may be attributed to the state of the soil structure at $50 \mathrm{~cm}$ distance away from the vetiver hedges which constituted the measurement. The gap between $25 \mathrm{~cm}$ and $50 \mathrm{~cm}$ in vetiver plots was so wide apart when compared with the non-vetiver plots. This is an indication of higher intake and conductivity of water at position near vetiver hedges resulting from the sink created by the vetiver roots that enhances infiltration. The point where the infiltration is low indicates potential high runoff on the plot. This confirms the reports of ${ }^{14}$ that vetiver hedges reduces runoff than the control plot. Infiltration characteristics of soils at $25 \mathrm{~cm}$ away from the vetiver hedges were comparatively higher than the infiltration points of $50 \mathrm{~cm}$ away from the vetiver hedges. The line graphs of cumulative infiltration against elapsed time revealed a continuous rise in water infiltration throughout the period of 120 minutes at all the points measured. Although there were some differences among the points, the mean value of equilibrium infiltration and cumulative infiltration at 120 minutes was relatively higher at $25 \mathrm{~cm}$ distance away from vetiver $(260.10 \mathrm{~cm} / 120 \mathrm{~min} .>195.4 \mathrm{~cm} / 120 \mathrm{~min})$. But when cumulative infiltration in vetiver plots when compared with the non - vetiver (control) the mean value of vetiver plot was higher than that of control $(455.50 \mathrm{~cm} / 120 \mathrm{~min} .>417.20 \mathrm{~cm} / 120 \mathrm{~min}$. $)$.

\section{Description of mapping units}

The descriptions of the soil mapping units are given below:

The soil map (Fig.1) of the farm is produced at a scale of 1:500. There is a clear relationship between soils and topographic positions within the project area. Largely, the depth of water, texture, relief and drainage, determine the soil characteristics. The soil is discussed under three major suitability classification of: Highly suitable, Suitable and moderately suitable..$^{15}$

Soil mapping unit class-A (5 and 7): The soils of this mapping unit are found exclusively within the area of latitude $05^{\circ} 01.912$ ' and $05^{\circ}$ $01.916^{\prime} \mathrm{N}$ and longitude $0758.239^{\prime}$ and $0758.231^{\prime} \mathrm{E}$. The land area is rated Suitable for arable cropping, but having limitations which in aggregate are moderately severe for sustained application of a given use (arable crop production); the limitations will reduce productivity or benefits and increase required inputs to the extent that the overall advantage to be gained from the arable cropping, although still attractive, will be appreciably inferior to that expected on class B land. The soil texture varies greatly from sand to sandy loam. The surface horizons have dark brown sand to sandy loam overlying brown to light subsoil with attendance surface crusting.

Soil mapping unit class-B (1,3,6and 9): The land area is rated Highly suitable in its present status. Located within latitude $05^{\circ}$ 01.906', $0501.912,0501.953$ and $05^{\circ} 01.927^{\prime} \mathrm{N}$ and longitude 07 58.242', 0758256,0758251 and $0758.249^{\prime}$ E. The land areas having no significant limitations to sustained application of a given use, or only minor limitations that will not significantly reduce productivity or benefits and will not raise inputs above an acceptable level. Soils of this unit are better drained, porous and heavily leached with dark greyish brown to strong brown sands to loamy sands on the surface being underlain by strong brown to reddish yellow fine sand to sandy 
loam in the subsoils. The soils are slightly acidic with high nutrient contents.

Soil mapping unit C (2,4 and 8): This mapping unit is rated moderately or conditionally suitable having limitations which in aggregate are poorly suitable for sustained application of a given use and will so reduce productivity or benefits, or increase required inputs, that this inputs will only be marginally justified. The problems in this land area arise from the interaction between characteristics. The hazards of soil erosion, poor soil drainage and low availability of oxygen in the root zone are limitations. The soils belonging to this mapping unit occur on recent alluvium of eroded materials. The soils are deep, poorly to very poorly drain with black to very black grey loamy sand top soils underlain by greyish brown to dark grayish brown sandy loam to loam sub soils. The soils are often mottled indicating poor drainage conditions prevailing in the soils.

\section{Conclusion}

There was continuous rise in water infiltration at $25 \mathrm{~cm}$ points near vetiver grass strips throughout the period of the experiments, whereas within short time, equilibrium infiltration rate was quickly noticed in no-vetiver plots. Runoff was directly proportional to fine sand content, but inversely related with total porosity and soil's sorptivity. This is because restricted infiltration enhances the accumulation of runoff and the hazard of erosion during a rainstorm. It also affects the availability of water in the soil and water economy of the rooting zone of plants. Generally, the infiltration category in no-vetiver plots was slow while that of the vetiver averaged moderate. Differences in degree of suitability are determined by the relationship between benefits and inputs. The benefits include crop products and services. The inputs needed to obtain such benefits comprise such things as capital investment, labour, fertilizers etc. thus the area of land classified as highly suitable for rainfed agriculture will produce crops value that substantially exceed the cost of farming, but land areas with suitable classification, will produce values only slightly higher than the costs of obtaining it. It should be expected that, locations with marginal or conditional suitability rating will need more expenditure that may not guaranteed returns that commensurate the additional inputs, except for short-season crops like vegetables during the short dry period of the year.

\section{Acknowledgements}

None.

\section{Conflict of interest}

The author declares no conflict of interest.

\section{References}

1. Aina PO. Soil changes resulting from long-term management practices in Western Nigeria. SSSA Journal. 1979;43(1):173-177.
2. Alabi RT, AG Ibiyemi. Rainfall in Nigeria and food crop production. In Akoroda MO editors. Agronomy in Nigeria. Nigeria: University of Ibadan; 2000. 63 p.

3. Angers DA, GR Mehuys. Aggregate stability to water: In MR Carter editors. Canadian Society of Soil Science. Lewis Publishers; 1993. p. 651-657.

4. Armstong JL. Runoff and soil loss from bare fallow plot at Inverell, New South ales. Australian Journal of Soil Research. 1990;28(4):659-675.

5. Babalola O. Soil properties affecting infiltration, runoff and erodibility. In VO Sagua, et al. editors. Ecological disasters in Nigeria. Soil Erosion, Fed. Lagos, Nigeria: Min Sci \& Tech; 2000. p. 131-156.

6. Babalola O, Oshunsanya SO, Are K. Effects of vetiver grass (Vetiverianigritana) strips, vetiver grass mulch and an organomineral fertilizer on soil, water and nutrient losses and maize (Zea mays, L) yields. Soil and Tillage Research. 2007;96:618.

7. Babalola $\mathrm{O}$, Jimba $\mathrm{SC}$, Maduakolam $\mathrm{O}$, et al. Use of vetiver grass for soil and water Conservation in Nigeria. In: Truong et al. editors. Proceedings of the third International Conference on Vetiver and Exhibition; Guangzhou, China: IEEE; 2002. p. 293300.

8. Hillel D. Introduction to soil physics. Orlando, SanDiego NY: Academic press publishers; 1982.

9. Kostiakov AN. On the Dynamics of the Coefficient of Water Percolation in Soilsand on the Necessity of studying it from Dynamic Point of View for the Purposes of Ameliorating. Trans Com Int Soc Soil Sci. 1932;Part A:17-21.

10. Mahler PJ. editors. Manual of multipurpose land classification. Publ. No. 212, Soil Institute of Iran. Ministry of Agriculture Teheran; $1970.81 \mathrm{p}$.

11. Nie NH, DH Bent, CH Hull. SPSS-Statistical package for social sciences. NY: Mc Graw-Hill Co; 1970. 343 p.

12. Philips JR. The theory of infiltration: 4 . Sorptivity and algebraic infiltration equations. Soil Sci. 1957;84(3):257-264.

13. Philip S. Soil Hydraulic conductivity and septic system performance. USDA-natural resources conservation; 2007.

14. Vink APA. Land use in advancing agriculture. Berlin, Heidelberg, New York: Springer; 2005. 392 p.

15. Young A. Tropical soils and soil survey. Cambridge University Press Cambridge; 2006. 468 P. 